\title{
Association of a novel single nucleotide polymorphism at the exon-2 of Insulin-Like Growth Factor 1 (IGF1) gene with phenotypic variants in goats
}

\author{
Thomas Naicy ${ }^{1 *}$, Thirupathy Venkatachalapathy ${ }^{2}$, \\ Thazhathuveettil Aravindakshan ${ }^{3}$, Kunniyoor C. Raghavan², \\ Mangattumuruppel Mini ${ }^{3}$, and Kulangara Shyama ${ }^{4}$ \\ ${ }^{1}$ Department of Animal Breeding, Genetics and Biostatistics, College of Veterinary and Animal Sciences, \\ Mannuthy, Thrissur, Kerala, India \\ ${ }^{2}$ Centre for Advanced Studies in Animal Genetics and Breeding, College of Veterinary and Animal Sciences, \\ Mannuthy, Thrissur, Kerala, India \\ ${ }^{3}$ Department of Veterinary Microbiology, College of Veterinary and Animal Sciences, Mannuthy, \\ Thrissur, Kerala, India \\ ${ }^{4}$ Department of Animal Nutrition, College of Veterinary and Animal Sciences, Mannuthy, \\ Thrissur, Kerala, India
}

NAICY, T., T. VENKATACHALAPATHY, T. ARAVINDAKSHAN, K. C.
RAGHAVAN, M. MINI, K. SHYAMA: Association of a novel single nucleotide
polymorphism at the exon-2 of Insulin-Like Growth Factor 1 (IGF1) gene with
phenotypic variants in goats. Vet. arhiv 87, 457-472, 2017. ABSTRACT

The Insulin-Like Growth Factor 1 plays a key role in foetal development and post natal growth. The objectives of this study were to characterise the complete coding sequence of caprine IGF1 gene in two indigenous goat breeds of India: Malabari and Attappady Black, to detect polymorphisms of IGF1 gene, to investigate their effects on body size traits and to ascertain the relative expression of IGF1 mRNA in muscle tissues of goats belonging to low and high body weight groups. All the four exons of caprine IGF1 gene were amplified and characterized by PCR-SSCP in 298 goats, revealing two genotypes (CC and CT) at exon 2. Sequencing of the PCR products from each genotype revealed a novel SNP, g.80C > T (GenBank accession No. KM974180), which caused a non-synonymous mutation (Thr48Met),causing differences in IGF1 protein structure. Association analysis of the loci indicated CT genotypes have higher body length $(\mathrm{P}<0.01)$, chest circumference $(\mathrm{P}<0.01)$ and body length index $(\mathrm{P}<0.05)$ than $\mathrm{CC}$ genotypes. Two novel PCR-RFLPs were designed for the rapid detection of the genotypes. The quantitative real time PCR demonstrated a difference in the expression of IGF1 mRNA in muscle tissues of the low and high body weight groups, but it was not significant $(\mathrm{P}>0.05)$. The results of the

\footnotetext{
*Corresponding author:

Dr. Naicy Thomas, M.V.Sc., PhD, Assis. Prof., Department of Animal Breeding, Genetics and Biostatistics, College of Veterinary and Animal Sciences, Mannuthy, Thrissur-680651, Kerala, India, Phone: +91 944611 9307; E-mail: naicy@kvasu.ac.in
} 
T. Naicy et al.: Association of IGF1 gene polymorphism with phenotypic variants in goats

present study suggest that the alleles of the IGF1 gene could be considered as strong targets for improvement of growth traits in goats.

Key words: goat, gene expression, growth, insulin-like growth factor 1, single-strand conformation polymorphism, qRT-PCR, single nucleotide polymorphism

\section{Introduction}

Detection of candidate genes or markers responsible for the phenotypic variation in production traits remains a major challenge in genetic improvement programmes. Identification of direct markers is more useful than indirect markers for predicting the phenotypic superiority of the targeted traits of a population (DEKKERS, 2004; WILLIAMS, 2005; ZHANG et al., 2011). In animals, growth is regulated by a complex system, in which the somatotropic axis plays an important role (BUYSE and DECUYPERE, 1999). The somatotropic axis contains genes for growth hormone $(\mathrm{GH})$, insulin-like growth factors (IGF1 and 2), their binding proteins and receptors. Growth hormone influences the growth of bones and muscles, which is mediated by IGF1, the key factor for postnatal growth (SELLIER, 2000). IGF1 has an important role in multiple biological functions as key regulator molecules that affect the proliferation of cells, mitosis, myogenesis, meiosis, differentiation and reproduction (LIU et al., 1993; EWTON et al., 1994; FLORINI et al., 1996; FURSTENBERGER and SENN, 2002; LAVIOLA et al., 2007; BARTON et al., 2012; THOMAS et al., 2016). It also stimulates glucose absorption, lipogenesis, myogenesis and progesterone synthesis in granulose cells, inhibition of cell death, activation of cell cycle genes etc. (REYNA et al., 2010). The growth retardation in both mice and humans due to mutations inw IGF1 gene (LIU et al., 1993; ARENDS et al., 2002), indicates its central role in growth. A microsatellite polymorphism in the IGF1 gene has been reported as a putative QTL (quantitative trait loci) marker for birth weight in cattle (MACHADO et al., 2003). ZHANG et al. (2008) reported a new SNP (G to C transversion) in intron 4 of the caprine IGF1 gene associated with birth weight, body weight at six months and twelve months, heart girth at two months, body length at six months, six and twelve month wither height, and heart girth at twelve months. SHARMA et al. (2013) detected 18 SNPs of the IGF1 gene in nine Indian breeds of goat, of which nine SNPs were in the coding region with synonymous mutation. They noticed a significant association between SNPs and body weight in different age groups in Sirohi goats.

The IGF1 gene plays an important role in prenatal and postnatal growth in several livestock species. In Ovis aries, IGF1 promotes growth of foetal organs, endocrine glands and skeletal maturation by enhancing foetal amino acid and glucose uptake (LOK et al., 1996; JENSEN et al., 1999). In postnatal life, IGF1 is a key component in the linear growth of animals, as a result of its longitudinal bone growth, cartilage growth and muscle growth (YAKAR et al., 2002). Due to the various critical roles of IGF1 gene in prenatal as well as postnatal growth, this gene has been considered as a candidate gene associated with growth and carcass traits in livestock species. The association of genetic polymorphisms 
T. Naicy et al.: Association of IGF1 gene polymorphism with phenotypic variants in goats

of the IGF1 gene with growth traits have been reported in caprine (DENG et al., 2010; QIONG et al., 2011; SHARMA et al., 2013), bovines (CHUNG and KIM, 2005; BENNETT et al., 2006), swine (CASS et al., 1997; ESTANY et al., 2007; NIU et al., 2013), chickens (AMILLS et al., 2003; WANG et al., 2004) Atlantic Salmon (TSAI et al., 2014) and common carp (FENG et al., 2014).

The present study was designed to analyse the genetic variations of the IGF1 gene and their association with body size traits in 298 goats of the Attappady Black and Malabari breeds in Kerala, India. The various phenotypic traits of economic importance included in the association study in the current research were body length, body height, trunk, chest and cannon circumferences, body length index, chest circumference index, cannon circumference index and trunk index. The genetic association analysis of the IGF1 gene with these traits would be useful in future breeding plans as a marker for selection and genetic improvement of growth in goats.

\section{Materials and methods}

Blood and tissue sample collection for DNA and RNA isolation. To analyse the allelic variations of the caprine IGF1 gene, six millilitre of venous blood was collected from the jugular veins of a total of 298 adult female goats (2-5 years of age) belonging to the Malabari $(n=196)$ and Attappady Black breeds $(n=102)$ maintained at the University Goat and Sheep Farm, Mannuthy, Thrissur district, Kottakkal Aryavaidyasala, Malappuram district and the Department of Animal Husbandry Goat Farm, Attappady, Palakkad district, Kerala. The genomic DNA was extracted by the standard phenol chloroform method and stored at $-20{ }^{\circ} \mathrm{C}$ until use. The muscle tissues were collected from six animals each; from the $20-29 \mathrm{Kg}$ and $30-39 \mathrm{Kg}$ body weight groups, slaughtered at the Kerala Veterinary and Animal Science University Meat Plant. Approximately $100 \mathrm{mg}$ of the tissue was collected within 30 minutes of slaughter and immediately transported in RNAlater (Sigma-Aldrich) to the laboratory and stored at $-80^{\circ} \mathrm{C}$ until RNA isolation. Total RNA was extracted from the tissue samples using Gen Elute mammalian total RNA miniprep kit (RTN10, Sigma Aldrich), DNaseI treatment was done using a DNase1 kit (Sigma-Aldrich), to prevent genomic DNA contamination. The RNA samples were quantified by a NanoDrop spectrophotometer (Thermo Scientific, USA) and their integrities were checked in agarose gel (1\%). cDNA was synthesized from isolated RNA using a RevertAid first strand cDNA synthesis kit (Thermo Scientific, K1622) in a reaction volume of $20 \mu \mathrm{l}$ and stored at $-80^{\circ} \mathrm{C}$ until use.

Data collection. To evaluate the meat production related performance traits, the phenotypic traits of the goats, body length, chest circumference, body height, trunk circumference and cannon circumference were measured directly. Body length index, chest circumference index, cannon circumference index and trunk index were estimated as described in a previous association study (JIN et al., 2010). 
T. Naicy et al.: Association of IGF1 gene polymorphism with phenotypic variants in goats

PCR-SSCP and SNP identification. Four pairs of primers were designed from the caprine IGF1 gene sequence available in GenBank (Accession No. HQ731040), using primer3 software to amplify exons 1, 2, 3 and 4 of the $I G F 1$ gene, in order to perform PCR-SSCP. Primer sequences, expected amplicon size and annealing temperatures are listed in Table 1 . The $25 \mu \mathrm{L}$ reaction volume contained $50 \mathrm{ng}$ genomic DNA, $12.5 \mu \mathrm{L}$ $2 \mathrm{X}$ reaction buffer (including $1.5 \mathrm{mM}$ of $\mathrm{MgCl}_{2}$ ), $0.2 \mathrm{mM}$ dNTPs (Fermentas), $10 \mathrm{pM}$ of each primer, and $0.5 \mathrm{U}$ of Taq DNA polymerase (Sigma-Aldrich). The cyclic protocol was 3 min at $95{ }^{\circ} \mathrm{C}, 35$ cycles of denaturing at $94{ }^{\circ} \mathrm{C}$ for $30 \mathrm{~s}$, annealing at $\mathrm{X}{ }^{\circ} \mathrm{C}$ (Table 1) for $20 \mathrm{~s}$, extension at $72{ }^{\circ} \mathrm{C}$ for $30 \mathrm{~s}$ with a final extension at $72{ }^{\circ} \mathrm{C}$ for $5 \mathrm{~min}$ carried out in a thermal cycler (Applied Biosystems). 298 goats belonging to the two breeds were genotyped by PCR-SSCP. PCR products $(5 \mu \mathrm{L})$ were mixed with a $10 \mu \mathrm{L}$ denaturing dye ( $9.5 \mathrm{~mL}$ formamide deionized, $0.4 \mathrm{~mL}$ of $0.5 \mathrm{M}$ EDTA, $2.5 \mathrm{mg}$ xylene-cyanole and 2.5 $\mathrm{mg}$ bromophenol blue), centrifuged, denatured for 10 minutes at $95^{\circ} \mathrm{C}$ and snap cooled immediately on ice for 10 minutes. Denatured PCR products were subjected to $12 \%$ polyacrylamide gel electrophoresis (acrylamide:bisacrylamide = 29:1) in 1X TBE buffer at $4{ }^{\circ} \mathrm{C}$, in a vertical electrophoresis apparatus (Hoefer, USA) at 140-170 volts for 16 hours. The band patterns of SSCP were visualized by staining with $0.2 \%$ silver nitrate, photographed and analysed. The PCR products from each genotype were sequenced to detect nucleotide variations and aligned with other sequences in GenBank employing BLASTn from NCBI.

Table 1. Primer sequence, exon number, amplicon size, region covered by each primer and annealing temperatures for the primers used for characterisation of caprine IGF1 by PCR-SSCP and for qRT PCR

\begin{tabular}{|c|c|c|c|c|}
\hline $\begin{array}{l}\text { Primer } \\
\text { name }\end{array}$ & Primer sequence $\left(5^{\prime}-3^{\prime}\right)$ & Exon & $\begin{array}{l}\text { Amplicon } \\
\text { size in bp }\end{array}$ & $\begin{array}{c}\text { Annealing } \\
\text { temp. }\left(\mathrm{X}^{\circ} \mathrm{C}\right)\end{array}$ \\
\hline P1-F & 5'-AGGATGTGCTCGAAATCCCT-3' & \multirow{2}{*}{ Exon1 } & 300 & \multirow{2}{*}{61} \\
\hline P1-R & 5' -TTCCCCAATGACTTCAAAGAGT-3' & & $(1936-2235)$ & \\
\hline $\mathrm{P} 2-\mathrm{F}$ & 5' -CAGGTGAAGATGCCAGTCAC -3' & \multirow[b]{2}{*}{ Exon2 } & \multirow[b]{2}{*}{$\begin{array}{c}180 \\
(4765-4944)\end{array}$} & \multirow[b]{2}{*}{61} \\
\hline P2-R & 5'-GCGAGAGGGAGGCTACTTAC-3' & & & \\
\hline P3-F & 5'-TTTGAACAGACAAGCCCACG -3' & \multirow{2}{*}{ Exon3 } & 197 & \multirow{2}{*}{58} \\
\hline P3-R & 5'-GCTTACCTTCTGAGCCTTGG-3' & & $(5530-5726)$ & \\
\hline P4-F & 5'-AGGAAGTACATTTGAAGAACAC-3' & \multirow{2}{*}{ Exon4 } & 240 & \multirow{2}{*}{61} \\
\hline P4-R & 5'-ACAATCACTCCTAAAGACCATGT-3' & & $(6087-6326)$ & \\
\hline IRT-F & 5'-CATCCTCCTCGCATCTCTTC-3' & \multirow{2}{*}{$\begin{array}{c}\text { IGF1 } \\
\text { (qRT PCR) }\end{array}$} & \multirow{2}{*}{111} & \multirow{2}{*}{60} \\
\hline IRT-R & 5'-ACTGGAGAGCATCCACCAAC-3' & & & \\
\hline Bactin-F & 5' -CCACACCTTCTACAACGAGC-3' & \multirow{2}{*}{$\mid \begin{array}{c}\beta \text {-actin } \\
(\mathrm{qRT} \text { PCR) }\end{array}$} & \multirow{2}{*}{105} & \multirow{2}{*}{60} \\
\hline Bactin-R & 5'-ATCTGGGTCATCTTCTCACG-3' & & & \\
\hline
\end{tabular}


Designing of two novel PCR -RFLPs for the novel SNP. The PCR-RFLP protocol was formulated using the restriction enzymes NcoI (Fermentas, India) and NlaIII (NEB) for simple and quick genotyping of the samples. Aliquots of $5 \mu \mathrm{L}$ PCR products of different genotypes of IGF1 gene exon 2 were digested with $10 \mathrm{U}$ restriction enzymes for $1 \mathrm{~h}$ at 37 ${ }^{\circ} \mathrm{C}$ following the supplier's directions, in separate reaction tubes. The digested products were detected by $8 \%$ polyacrylamide gel electrophoresis.

Analysis of predicted protein sequences. The intronic regions were removed from the sequences and exonic regions were aligned. The predicted amino acid sequences (http:// web.expasy.org/translate/) of different genotypes were compared with pair wise sequence alignment of EMBOSS Needle (http://www.ebi.ac.uk/Tools/psa/emboss_needle/). The self-optimized prediction method (SOPMA) was used to predict the number of alpha helices, beta turns, random coils and extended strands in the predicted IGF1 proteins of both genotypes (https://npsa-prabi.ibcp.fr/). Molecular weight, theoretical pI (isoelectric point) and GRAVY (Grand Average Hydropathicity) were predicted using the ProtParam tool (http://web.expasy.org/protparam/). All these parameters were compared between the predicted amino acid sequences of the two genotypes.

Statistical analysis. The allelic frequencies, genotype frequencies, observed heterozygosity, expected heterozygosity, observed number of alleles and effective number of alleles were estimated using Popgene32 (Version 1.32). The association between IGF1 genotypes with different measurements of phenotypic traits were analysed using the following general linear model:

$$
y_{i j k l}=\mu+b_{i}+c_{j}+g_{k}+e_{i j k l}
$$

Where, $\mathrm{y}_{\mathrm{ijkl}}$ is the growth trait measured on the $\mathrm{ijk} \mathrm{k}^{\text {th }}$ animal (body length, chest circumference, body height, trunk circumference, cannon circumference, body length index, chest circumference index, cannon circumference index and trunk index), $\mu$ is the mean for the entire population, $b_{i}$ is the fixed effect associated with $i^{\text {th }}$ breed $(i=1,2), c_{j}$ is the fixed effect associated with the $j^{\text {th }}$ centre $(j=1,2,3), g_{k}$ is the fixed effect associated with the $\mathrm{k}^{\text {th }}$ genotype $(\mathrm{k}=1,2)$ and $\mathrm{e}_{\mathrm{ijk} \mathrm{l}}$ is the random error.

Reverse Transcriptase-quantitative real-time PCR ( $q R T$ PCR). The IGF1 gene expression in the muscle tissues of animals belonging to the two body weight groups (20-29 $\mathrm{Kg}$ and $30-39 \mathrm{Kg}$ ) was measured by qRT RCR using SYBR green chemistry (Thermo Scientific), carried out using the Illumina $\mathrm{Eco}^{\circledR}$ Q-RT PCR system. The fold changes in the gene expression were normalized by the expression levels of Beta-actin gene. Primer pairs for caprine IGF1 and Beta-actin were designed using Primer3 software (Table 1). qRT-PCR was carried out in $25 \mu 1$ reaction volume, containing $50 \mathrm{ng}$ of cDNA and 2X Maxima SYBR Green/ROX qPCR Master Mix (Thermo Scientific). The cyclic conditions were, $95{ }^{\circ} \mathrm{C}$ for three min, followed by 40 cycles of $95{ }^{\circ} \mathrm{C}$ for $30 \mathrm{~s}, 60^{\circ} \mathrm{C}$ for 
T. Naicy et al.: Association of IGF1 gene polymorphism with phenotypic variants in goats

$15 \mathrm{~s}, 72{ }^{\circ} \mathrm{C}$ for $30 \mathrm{~s}$ and finally for dissociation curve analysis, $95{ }^{\circ} \mathrm{C}$ for $15 \mathrm{~s}, 60{ }^{\circ} \mathrm{C}$ for $15 \mathrm{~s}$ and $95^{\circ} \mathrm{C}$ for $15 \mathrm{~s}$. The relative expression of IGF1 mRNA in the two groups was calculated by the $2^{-\Delta \Delta C t}$ method described by LIVAK and SCHMITTGEN (2001).

\section{Results}

Identification of polymorphism in the caprine IGF1 gene. In the goat the IGF1 gene is encoded by a single gene located on chromosome 5. The IGF1 gene exons 1, 2, 3 and 4 were amplified by the P1-P4 primer pairs (Fig. 1). The SSCP patterns of $300 \mathrm{bp}, 197 \mathrm{bp}$ and 240 bp fragments (primer pairs, P1, P3 and P4) exhibited monomorphic band patterns (Fig. 2-4). The SSCP of the 180 bp fragment (exon 2) exhibited polymorphic banding pattern (Fig. 5) with two and three band patterns. Sequencing the PCR products from each genotype revealed one mutation in the $\mathrm{CT}$ genotype $\left(\mathrm{C} \rightarrow \mathrm{T}\right.$ transition at $80^{\text {th }}$ position). The sequencing maps are displayed in Fig. 6. Differences in allele frequencies of the IGF1 exon 2 in Malabari and Attappady Black breeds are presented in Table 2. The allelic and genotypic frequencies were significantly different between the two breeds $(\mathrm{P}<0.01)$. The population genetics indices, observed heterozygosity $\left(\mathrm{H}_{\mathrm{o}}\right)$, expected heterozygosity $\left(H_{e}\right)$, observed number of alleles $\left(n_{a}\right)$ and effective number of alleles $\left(n_{e}\right)$ for the locus are presented in Table 3. The sequence of the new genetic variant (CT genotype of exon 2 of IGF1) was submitted to GenBank (Accession No. KM974180). PCR products of exon 1, 3 and 4 of IGF1 were sequenced and submitted to GenBank (Accession No. KM974181 (exon 1 and 2 of Attappady Black), KP256000 and KP256001 (exon 3 of Malabari and Attappady Black) and KT274023 (exon 4)). Novel PCR-RFLPs were designed using the restriction enzymes NcoI (Fermentas) and NlaIII (NEB).

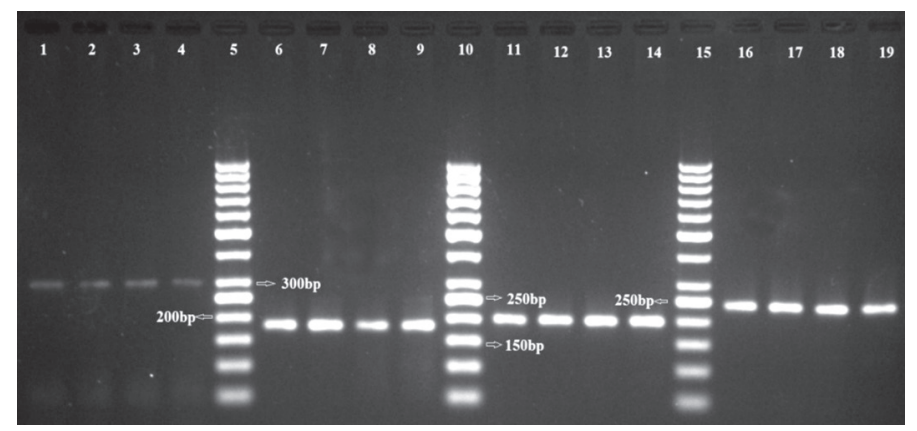

Fig. 1. The IGF1 gene exons 1, 2, 3 and 4 amplified by the P1-P4 primers. Lane1-4:300 bp of exon 1, Lane 6-9:180bp of exon 2, Lane 11-14 :197bp of exon 3, Lane 16-19:240 bp of exon 4, Lane 5,10,15: 50 bp DNA marker (Fermentas, India) 
T. Naicy et al.: Association of IGF1 gene polymorphism with phenotypic variants in goats

Table 2. Genotype and allelic frequencies of $180 \mathrm{bp}$ fragment of IGF1 gene of goat based SSCP pattern

\begin{tabular}{|l|c|c|c|c|c|}
\hline \multirow{2}{*}{ Breed } & \multicolumn{2}{|c|}{ Genotype frequency } & \multicolumn{2}{|c|}{ Allelic frequency } & \multirow{2}{*}{ P value } \\
\cline { 2 - 5 } & $\mathrm{CC}$ & $\mathrm{CT}$ & $\mathrm{C}$ & $\mathrm{T}$ & \\
\hline \multirow{2}{*}{ Malabari (196) } & $\begin{array}{c}0.90 \\
(176)\end{array}$ & $\begin{array}{c}0.10 \\
(20)\end{array}$ & $0.95(372)$ & $\begin{array}{c}0.05 \\
(20)\end{array}$ & \\
\hline Attapady (102) & $\begin{array}{c}1.00 \\
(102)\end{array}$ & $\begin{array}{c}0.00 \\
(0)\end{array}$ & $1.00(204)$ & $0.00(0)$ & \\
\cline { 1 - 4 } Total (298) & $\begin{array}{c}0.93 \\
(278)\end{array}$ & $\begin{array}{c}0.07 \\
(20)\end{array}$ & $0.97(576)$ & $0.03(20)$ & \\
\hline
\end{tabular}

Genotypic and allelic frequency differences between breeds were significant $(\mathrm{P}<0.01)$

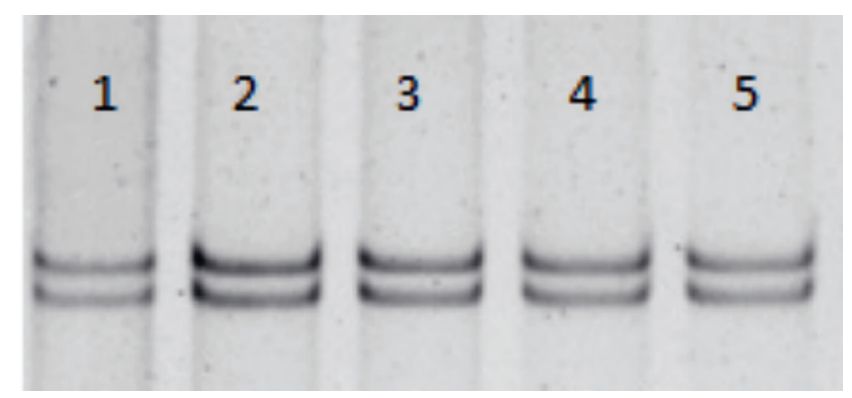

Fig. 2. PCR-SSCP pattern of 300bp fragment of IGF1 exon 1. All 298 goats were found to be monomorphic for this locus

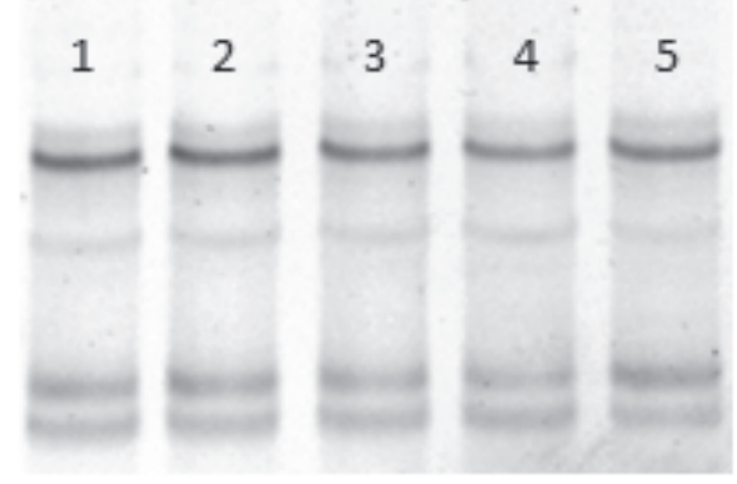

Fig. 3. PCR-SSCP pattern of 197bp fragment of IGF1 exon 3. All 298 goats were found to be monomorphic for this locus 
T. Naicy et al.: Association of IGF1 gene polymorphism with phenotypic variants in goats

Table 3. Genetic indices of IGF1 exon 2 in goat population

\begin{tabular}{|c|c|c|c|c|}
\hline Locus & $\begin{array}{c}\text { Observed } \\
\text { Heterozygosity }\left(\mathrm{H}_{\mathrm{o}}\right)\end{array}$ & $\begin{array}{c}\text { Expected } \\
\text { heterozygosity }\left(\mathrm{H}_{\mathrm{e}}\right)\end{array}$ & No. of alleles $\left(\mathrm{n}_{\mathrm{a}}\right)$ & $\begin{array}{c}\text { Effective number } \\
\text { of alleles }\left(\mathrm{n}_{\mathrm{e}}\right)\end{array}$ \\
\hline g.80C $>\mathrm{T}$ & 0.04 & 0.04 & 2 & 1.04 \\
\hline
\end{tabular}

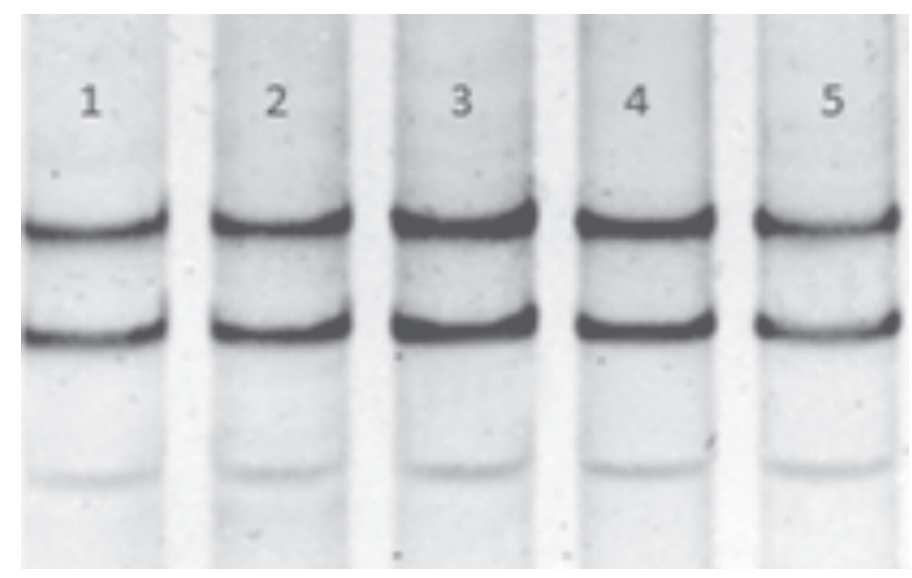

Fig. 4. PCR-SSCP pattern of 240bp fragment of IGF1 exon 4. All 298 goats were found to be monomorphic for this locus.

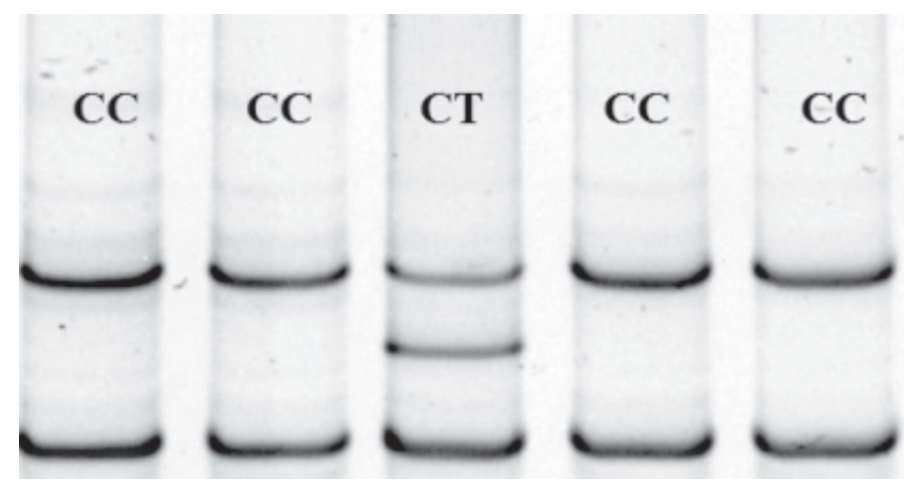

Fig. 5. PCR-SSCP pattern of 180bp fragment of IGF1exon 2 with CC and CT genotypes 


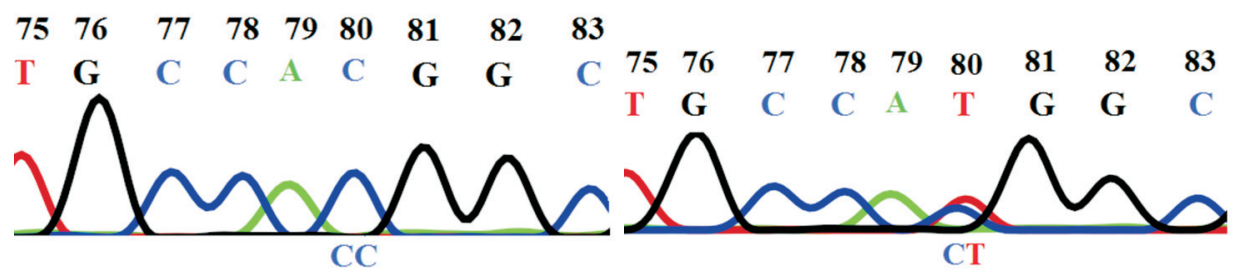

Fig. 6. Sequence map of CC genotype 180bp fragment of IGF1 exon 2 and discovery of a single nucleotide polymorphism (SNP) g.80C $>\mathrm{T}$ in exon 2

Table 4. The IGF1 genotypes association with body measurement traits given as least square means with standard error $(\mathrm{LSM} \pm \mathrm{SE})$

\begin{tabular}{|l|c|c|c|}
\hline \multirow{2}{*}{ Traits } & CC & CT & \multirow{2}{*}{ P value } \\
\cline { 2 - 4 } & LSM \pm SE & LSM \pm SE & $<0.01$ \\
\hline Body length $(\mathrm{cm})$ & $64.54 \pm 0.49^{\mathrm{a}}$ & $71.78 \pm 2.24^{\mathrm{b}}$ & 0.08 \\
\hline Body height $(\mathrm{cm})$ & $59.99 \pm 0.30$ & $62.37 \pm 1.38$ & $<0.01$ \\
\hline Chest circumference $(\mathrm{cm})$ & $72.94 \pm 0.41^{\mathrm{a}}$ & $78.35 \pm 1.90^{\mathrm{b}}$ & 0.15 \\
\hline Trunk circumference $(\mathrm{cm})$ & $80.23 \pm 0.52$ & $83.65 \pm 2.41$ & 0.08 \\
\hline Canon circumference $(\mathrm{cm})$ & $7.80 \pm 0.05$ & $8.17 \pm 0.22$ & 0.04 \\
\hline Body length index $(\%)$ & $108.72 \pm 0.99^{\mathrm{a}}$ & $118.30 \pm 4.55^{\mathrm{b}}$ & 0.09 \\
\hline Chest circumference index $(\%)$ & $124.04 \pm 0.53$ & $128.21 \pm 2.45$ & 0.65 \\
\hline Canon circumference index (\%) & $13.21 \pm 0.11$ & $13.43 \pm 0.49$ & 0.69 \\
\hline Trunk index $(\%)$ & $113.46 \pm 1.08$ & $115.44 \pm 4.95$ & \\
\hline
\end{tabular}

Means with different superscripts in the same row differ significantly $(\mathrm{P}<0.05)$

Table 5. Comparison of protein structure of IGF1 between two genotypes

\begin{tabular}{|l|c|c|}
\hline Parameter & Threonine at $48^{\text {th }}$ position & Methionine at $48^{\text {th }}$ position \\
\hline Alpha Helices & 48 & 56 \\
\hline Beta turns & 10 & 10 \\
\hline Extended strands & 21 & 17 \\
\hline Random coils & 75 & 71 \\
\hline Molecular weight $(\mathrm{KDa})$ & 17.08 & 17.11 \\
\hline Theoretical pI & 9.36 & 9.36 \\
\hline GRAVY & -0.267 & -0.250 \\
\hline
\end{tabular}

Association of IGF1 genotypes with growth traits in goats. Some of the investigated growth traits in goats were significantly affected by the IGF1 genotypes (g.80C $>$ T). The 
least square means with standard error for growth traits for different IGF1 genotypes are given in Table 4. All the traits considered showed higher phenotypic values for CT genotypes, with a significantly higher body length, chest circumference and body length index $(\mathrm{P}<0.05)$ than $\mathrm{CC}$ genotypes at the $\mathrm{P} 2$ locus. The contribution of this locus to the total phenotypic variability in growth traits for heterozygotes (CT) varied from 7 to $10 \%$.

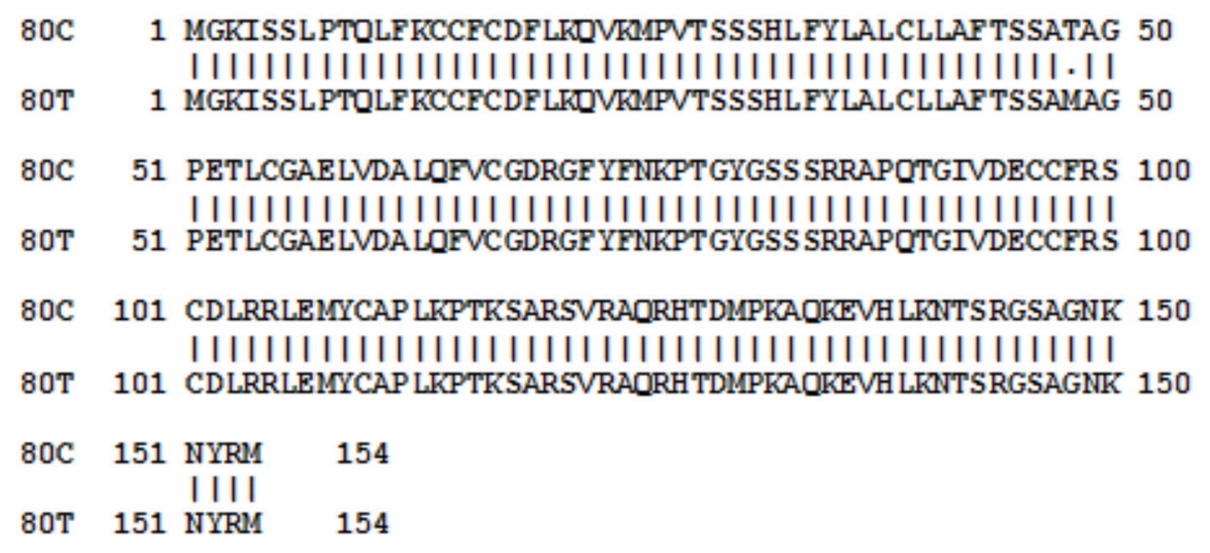

Fig. 7. The pair wise sequence alignment of predicted amino acid sequences of CC and CT genotypes (154 amino acids long peptide) of IGF1 peptide showing a single amino acid change at the $48^{\text {th }}$ position corresponding to $\mathrm{g} .80 \mathrm{C}>\mathrm{T}$ in exon 2

Analysis of predicted protein sequences. The predicted amino acid sequences of CC and CT genotypes (154 amino acids long peptide), compared by pair wise sequence alignment showed single amino acid change at the $48^{\text {th }}$ position (Fig. 7). Analysis of the sequences revealed substitution of nonpolar Methionine (codon ATG) in place of hydrophilic (polar) Threonine (codon ACG). The number of alpha helices, beta turns, random coils, extended strands, molecular weight, theoretical pI, Instability index and GRAVY were compared between two genotypes (Table 5). The numerical differences indicate the differences in the secondary structure of the IGF1 protein between the two genotypes. CC genotypes showed a slightly lower molecular weight for the IGF1 protein compared to CT genotypes. The GRAVY value indicates an increased hydropathicity for methionine substitution.

Reverse Transcriptase-quantitative real-time PCR ( $q R T$ PCR). The IGF1 mRNA expression levels in the muscle tissues of goats belonging to the two body weight groups (20-29 $\mathrm{Kg}$ and 30-39 Kg) were compared. The IGF1 gene exhibited a higher mRNA expression in muscle tissues in the higher body weight group (30-39 Kg) than the lower body weight group (20-29 Kg), but the difference was not significant $(\mathrm{P}>0.05)$ (Fig. 8). 
T. Naicy et al.: Association of IGF1 gene polymorphism with phenotypic variants in goats

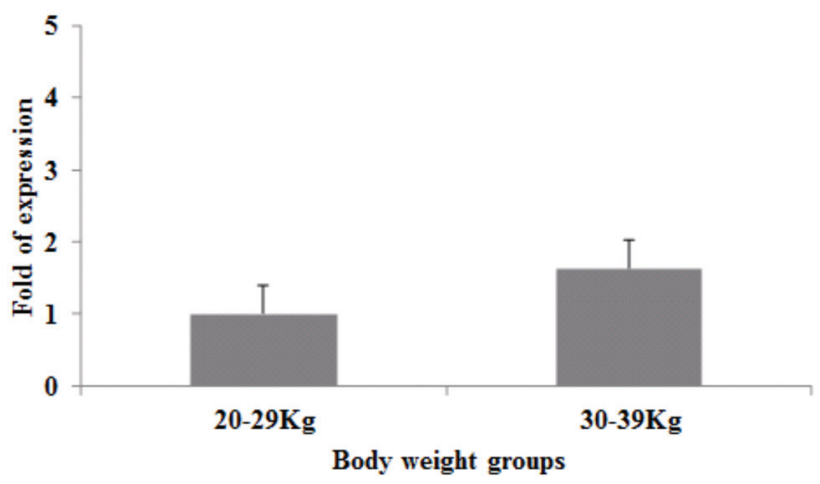

Fig. 8. Relative IGF1 mRNA expression levels in the muscle tissues of different body weight groups of goats showing a higher expression level in the $30-39 \mathrm{Kg}$ group, but the difference was non-significant $(\mathrm{P}>0.05)$. The fold changes in the gene expression were normalized by the expression levels of Beta actin gene (reference gene).

\section{Discussion}

Growth is a complex process, which is influenced by genetic, nutritional, environmental factors, and genotype-environmental interactions. Growth traits such as body length, height, trunk, chest and cannon circumference, body length index, chest circumference index, cannon circumference index and trunk index, have an important impact on the profitability of the goat industry. Therefore, selective breeding for optimal body conformation traits for maximum gain is vital in goat breeding programs.

The PCR-SSCP analysis of the IGF1 gene revealed only one SNP at exon 2, indicating the highly conserved nature of the IGF1 gene as reported in many studies (WALLIS, 2009; PHILIPPOU et al., 2014; THOMAS et al., 2016). The genotypes observed were CC and CT. The TT genotype was absent in the screened population, which might be due to the small sample size or the extremely low frequency of the $\mathrm{T}$ allele. The missing genotypes of the IGF1 gene loci may have negative effects on individual performance, so individuals with the missing genotypes have been eliminated by selection from breeding programmes (BEUZEN et al., 2000; VAN MARLE-KOSTER and NEL, 2003). We inferred that heterozygotes may increase hybrid vigour. Sequencing of PCR products from each genotype revealed a novel SNP, g.80C $>$ T, and a non-synonymous mutation (hydrophilic (polar) Threonine to nonpolar Methionine) in exon 2. All the growth traits showed higher phenotypic values for methionine substitution, where the values were significantly higher for body length, chest circumference and body length index. Since the detected mutation is non-synonymous, it has a crucial role in the change in structure and molecular weight 
of the IGF1 protein. The number of alpha helices, random coils and extended strands in the predicted IGF1 proteins of both genotypes showed numerical differences, signifying the variation in the structure of the IGF1 protein between the two genotypes. The GRAVY value was higher for the mutant genotype, indicating an increase in the hydropathicity of the IGF1 protein. These changes might be the reasons for the significant association between IGF1 polymorphism and growth traits.

The somatotropic axis plays a key role in the complex system of animal growth because of its important role in embryonic development, post natal growth and metabolism in mammals (YAKAR et al., 2002). The novel IGF1 SNP detected in the current study might have a practical application in caprine MAS programs, although verification studies in additional populations will be useful to analyse the robustness of this association with growth traits. In the current research, only one SNP was detected in the IGF1 gene, which may reflect the highly conserved nature of the IGF1 gene sequence, so genetic diversity studies could not be carried out. The SNP, g.80C $>$ T of the IGF1 gene could be used as a molecular marker for superior growth characteristics. We designed two novel PCRRFLPs as an appropriate tool for easy evaluation of genetic variability for the new SNP. Further, the expression levels of the IGF1 gene in muscle tissues was quantified in heavier and lighter goats with qRT PCR, and the heavier goats showed a higher level of mRNA expression compared to the lighter goats, even though the difference was insignificant. This might be due to the small number of animals in each group.

\section{Conclusions}

The present study investigated polymorphisms in the IGF1 gene and demonstrated a significant association of g. $80 \mathrm{C}>\mathrm{T}$ with growth traits in the tested population of goats. Since no other information is available on this novel SNP, further investigations are needed encompassing many breeds, as well as other livestock species, in order to verify the associated effects of SNP g.80C $>$ T of the IGF1 gene. The SNP identified in the current study may be characterized by functional genomics studies, as well as in a large population for further validation. The results will certainly provide a greater insight into the influence of genetic variants of IGF1 on growth performance traits, for utilization as a marker in genetic improvement programs in goats.

\footnotetext{
Acknowledgements

The authors are grateful to Kerala Veterinary and Animal Sciences University, Kerala, India, for providing the financial assistance and necessary facilities to carry out the research work.
}

\section{Conflicts of interest}

The authors report no conflicts of interest to disclose. 
T. Naicy et al.: Association of IGF1 gene polymorphism with phenotypic variants in goats

\section{References}

AMILLS, M., N. JIMENEZ, D. VILLALBA, M. TOR, E. MOLINA, D. CUBILO, C. MARCOS, A. FRANCESCH, A. SANCHEZ, J. ESTANY (2003): Identification of three single nucleotide polymorphisms in the chicken insulin-like growth factor 1 and 2 genes and their associations with growth and feeding traits. Poultry Sci. 82, 1485-1493.

ARENDS, N., L. JOHNSTON, A. HOKKEN-KOELEGA, C. VAN DUIJN, M. DE RIDDER, M. SAVAGE, A. CLARK (2002): Polymorphism in the IGF-I gene: Clinical relevance for short children born small for gestational age (SGA). J. Clin. Endocrinol. Metab. 87, 2720-2724.

BARTON, E. R., S. PARK, J. K. JAMES, C. A. MAKAREWICH, A. PHILIPPOU, D. ELETTO, H. LEI, B. BRISSON, O. OSTROVSKY, Z. LI, Y. ARGON (2012): Deletion of muscle GRP94 impairs both muscle and body growth by inhibiting local IGF production. FASEB J. 26, 36913702.

BENNETT, A. K., P. Y. HESTER, D. E. SPURLOCK (2006): Polymorphisms in vitamin D receptor, osteopontin, insulin-like growth factor 1 and insulin and their association with bone, egg and growth traits in a layer-broiler cross in chickens. Anim. Genet. 37, 283-286.

BUYSE, J., E. DECUYPERE (1999): The role of the somatotrophic axis in the metabolism of the chicken. Domest. Anim. Endocrinol. 17, 245-255.

BEUZEN, N. D., M. J. STEAR, K. C. CHANG (2000): Molecular markers and their use in animal breeding. Vet. J. 160, 42-52.

CASS, E., A. PRILL, S. G. PRICE, A. C. CLUTTER, B. W. KIRKPATRICK (1997): Relationship of growth hormone and insulin-like growth factors-1 genotypes with growth and carcass traits in swine. Anim. Genet. 28, 88-93.

CHUNG, E. R., W. T. KIM (2005): Association of SNP marker in IGF-1 and MYF5 candidate genes with growth traits in Korean cattle. Asian Australas. J. Anim. 18, 1061-1065.

DEKKERS, J. C. (2004): Commercial application of marker- and gene-assisted selection in livestock: strategies and lessons. J. Anim. Sci. 82, 313-328.

DENG, C., R. MA, X. YUE, X. LAN, H. CHEN, C. LEI (2010): Association of IGF-I gene polymorphisms with milk yield and body size in Chinese dairy goats. Genet. Mol. Biol. 33, 266-270.

ESTANY, J., M. TOR, D. VILLALBA, L. BOSCH, D. GALLARDO, N. JIMENEZ, L. ALTET, J. L. NOGUERA, J. REIXACH, M. AMILLS, A. SANCHEZ (2007): Association of CA repeat polymorphism at intron 1 of insulin-like growth factor (IGF-I) gene with circulating IGF-I concentration, growth, and fatness in swine. Physiol. Genomics 31, 236-243.

EWTON, D. Z., S. L. ROOF, K. A. MAGRI, F. J. MCWADE, J. R. FLORINI (1994): IGF-II is more active than IGF-I in stimulating L6A1 myogenesis: greater mitogenic actions of IGF-I delay differentiation. J. Cell. Physiol. 161, 277-284.

FENG, X., X. YU, J. TONG (2014): Novel single nucleotide polymorphisms of the insulin-like growth factor-I gene and their associations with growth traits in common carp (Cyprinus carpio L.). Int. J. Mol. Sci. 15, 22471-22482. 
T. Naicy et al.: Association of IGF1 gene polymorphism with phenotypic variants in goats

FLORINI, J. R., D. Z. EWTON, S. A. COOLICAN (1996): Growth hormone and the insulin-like growth factor system in myogenesis. Endocr. Rev. 17, 481-517.

FURSTENBERGER, G., H. J. SENN (2002): Insulin-like growth factors and cancer. Lancet Oncol. 3, 298-302.

JENSEN, E. C., J. E. HARDING, M. K. BAUER, P. D. GLUCKMAN (1999): Metabolic effects of IGF-I in the growth retarded fetal sheep. J. Endocrinol. 161, 485-494.

JIN, Q. J., X. T. FANG, C. L. ZHANG, L. YANG, J. J. SUN, D. X. CHEN, X. Y. SHI, Y. DU, X. Y. LAN, H. CHEN (2010): A novel SNP of the GHRL gene and its association with growth traits. Small Rumin. Res. 90, 150-152.

LAVIOLA, L., A. NATALICCHIO, F. GIORGINO (2007): The IGF-I signaling pathway. Curr. Pharm. Des. 13, 663-669.

LIU, J. P., J. BAKER, A. S. PERKINS, E. J. ROBERTSON, A. EFSTRATIADIS (1993): Mice carrying null mutations of the genes encoding insulin-like growth factor I (Igf-1) and type 1 IGF receptor (Igflr). Cell 75, 59-72.

LIVAK, K. J., T. W. SCHMITTGEN (2001): Analysis of relative gene expression data using realtime quantitative PCR and the $2^{-\Delta \Delta C}$ method. Methods $25,402-408$.

LOK, F., J. A. OWENS, L. MUNDY, J. S. ROBINSON, P. C. OWENS (1996): Insulin-like growth factor 1 promotes growth selectively in fetal sheep in late gestation. Am. J. Physiol. Regul. Integr. Comp. Physiol. 270, 1148-1155.

MACHADO, M. B. B., M. M. ALENCAR, A. P. PEREIRA, H. N. OLIVEIRA, E. CASAS, L. L. COUTINHO, L. C. A. REGITANO (2003): QTL affecting body weight in a candidate region of cattle chromosome 5. Genet. Mol. Biol. 26, 259-265.

NIU, P., S. W. KIM, B. H. CHOI, T. H. KIM, J. J. KIM, K. S. KIM (2013): Porcine insulin-like growth factor 1 (IGF1) gene polymorphisms are associated with body size variation. Genes Genom. 35, 523-528.

PHILIPPOU, A., M. MARIDAKI, S. PNEUMATICOS, M. KOUTSILIERIS (2014): The complexity of the IGF1 gene splicing, post-translational modification and bioactivity. Mol. Med. 20, 202-214.

QIONG, W., C. FANG, W. J. LIU, Y. FANG, Y. S. GANG (2011): A novel mutation at exon 4 of IGF-1 gene in three indigenous goat breeds in China. Asian J. Anim. Vet. Adv. 6 (6), 627-635.

REYNA, X. F., H. M. MONTOYA, V. V. CASTRELLON,A. M. S. RINCON, M. P. BRACAMONTE, W. A. VERA (2010): Polymorphisms in the IGF1 gene and their effect on growth traits in Mexican beef cattle. Genet. Mol. Res. 9, 875-883.

SELLIER, P. (2000): Genetically caused retarded growth in animals. Domest. Anim. Endocrinol. $19,105-119$.

SHARMA, A., G. DUTT, S. JAYAKUMAR, V. SAROHA, M. K. SINGH, O. P. PATHODIYA, B. S. KHADDAE, S. P. DIXIT (2013): Novel SNPs in IGF1, GHR and IGFBP-3 genes reveal significant association with growth traits in Indian goat breeds. Small Rumin. Res. 115, 7-14. 
T. Naicy et al:: Association of IGF1 gene polymorphism with phenotypic variants in goats

THOMAS, N., R. T. VENKATACHALAPATHY, T. V. ARAVINDAKSHAN, K. C. RAGHAVAN (2016): Molecular cloning, SNP detection and association analysis of 5' flanking region of the goat IGF1 gene with prolificacy. Anim. Reprod. Sci. 167, 8-15.

TSAI, H. Y., A. HAMILTON, D. R. GUY, R. D. HOUSTON (2014): Single nucleotide polymorphisms in the insulin-like growth factor 1 (IGF1) gene are associated with growthrelated traits in farmed Atlantic salmon. Anim. Genet. 45, 709-715.

VAN MARLE-KOSTER, E., L. H. NEL (2003): Genetic markers and their application in livestock breeding in South Africa: A review. South Afr. J. Anim. Sci. 33, 1-10.

WALLIS, M. (2009): New insulin-like growth factor (IGF)-precursor sequences from mammalian genomes: the molecular evolution of IGFs and associated peptides in primates. Growth Horm. IGF Res. 19, 12-23.

WANG, W. J., K. OUYANG, J. OUYANG, H. H. LI, S. M. LIN, H. SUN (2004): Polymorphism of insulin-like growth factor I gene in six chicken breeds and its relationship with growth traits. Asian Austral. J. Anim. 17, 301-304.

WILLIAMS, J. L. (2005): The use of marker-assisted selection in animal breeding and biotechnology. Rev. Sci. Tech. Off. Int. Epiz. 24, 379-391.

YAKAR, S., C. J. ROSEN, W. G. BEAMER, C. L. ACKERT-BICKNELL, Y. WU, J. L. LIU, T. O. GUCK, T.O. SETSER, J. FRYSTYK, Y. R. BOISCLAIR, D. LEROITH (2002): Circulating levels of IGF-1 directly regulate bone growth and density. J. Clin. Invest. 110, 771-781.

ZHANG, C., W. ZHANG, H. LUO, W. YUE, M. GAO, Z. JIA (2008): A new single nucleotide polymorphism in the IGF-I gene and its association with growth traits in the Nanjiang Huang goat. Asian Aust. J. Anim. Sci. 21, 1073-1079.

ZHANG, C., Y. LIU, K. HUANG, W. ZENG, D. XU, Q. WEN, L. YANG (2011): The association of two single nucleotide polymorphisms (SNPs) in growth hormone (GH) gene with litter size and superovulation response in goat-breeds. Genet. Mol. Biol. 34, 49-55.

Received: 29 February 2016

Accepted: 12 July 2016

NAICY, T., T. VENKATACHALAPATHY, T. ARAVINDAKSHAN, K. C. RAGHAVAN, M. MINI, K. SHYAMA: Povezanost novog polimorfizma pojedinačnog nukleotida u eksonu 2 gena za inzulinu sličan faktor rasta 1 (IGF1) $s$ fenotipskim varijantama u koza. Vet. arhiv 87, 457-472, 2017.

SAŽETAK

Inzulinu sličan faktor rasta 1 (IGF1) ima ključnu ulogu u razvoju ploda i postnatalnom rastu. Cilj je ovog istraživanja bio okarakterizirati cijelu kodirajuću sekvenciju IGF1 gena koza u dvije autohtone pasmine iz Indije: malabari i crna atapadi. S tim u vezi željelo se utvrditi polimorfizme IGF1 gena i istražiti njihove učinke na obilježja tjelesne razvijenosti, te ustanoviti relativnu ekspresiju IGF1 mRNA u mišićnom tkivu koza s malom i velikom tjelesnom masom. Kod 298 koza umnožena su sva 4 eksona IGF1 gena i okarakterizirana uz pomoć PCR-SSCP. Na eksonu 2 utvrđena su dva genotipa (CC i CT). Analiza sekvencije PCR produkata od svakog genotipa pokazala je novi polimorfizam pojedinačnog nukleotida, g. 80C > T (GenBank No. KM974180) koja je uzrokovala neistovjetnu mutaciju (Thr48Met) i razlike u strukturi proteina IGF1. Analiza povezanosti lokusa 
T. Naicy et al.: Association of IGF1 gene polymorphism with phenotypic variants in goats

pokazala je da CT genotipovi imaju u odnosu na $\mathrm{CC}$ genotipove veću dužinu tijela $(\mathrm{P}<0,01)$, veći opseg prsiju $(\mathrm{P}<0,01)$ i veći indeks dužine tijela $(\mathrm{P}<0,05)$. Dva nova PCR-RFLP-a su označena za brzu detekciju genotipova. Kvantitativna PCR analiza u stvarnom vremenu pokazala je nesignifikantne razlike $(\mathrm{P}>0,05) \mathrm{u}$ ekspresiji IGF1 mRNA u mišićnom tkivu koza s malim i velikim tjelesnim masama. Rezultati istraživanja upućuju da bi alele IGF1 gena mogli smatrati ciljanom skupinom za unaprjeđenju obilježja rasta u koza.

Ključne riječi: koza, ekspresija gena, rast, IGF1, polimorfizam jednolančane konformacije, qRT-PCR, polimorfizam pojedinačnog nukleotida 